\title{
Dinkum Sands—A Recently Foundered Arctic Island
}

Author(s): Erk Reimnitz

Source: Journal of Coastal Research, :274-280.

Published By: Coastal Education and Research Foundation

DOI: http://dx.doi.org/10.2112/04-0167.1

URL: http://www.bioone.org/doi/full/10.2112/04-0167.1

BioOne (www.bioone.org) is a nonprofit, online aggregation of core research in the biological, ecological, and environmental sciences. BioOne provides a sustainable online platform for over 170 journals and books published by nonprofit societies, associations, museums, institutions, and presses.

Your use of this PDF, the BioOne Web site, and all posted and associated content indicates your acceptance of BioOne's Terms of Use, available at www.bioone.org/page/terms_of_use.

Usage of BioOne content is strictly limited to personal, educational, and non-commercial use. Commercial inquiries or rights and permissions requests should be directed to the individual publisher as copyright holder. 


\title{
Dinkum Sands-A Recently Foundered Arctic Island
}

\section{Erk Reimnitz}

U.S. Geological Survey

P.O. Box 2782

El Granada, CA 94018, U.S.A.

ereimnitz@earthlink.net

\section{ABSTRACT}

REIMNITZ, E., 2005. Dinkum Sands-a recently foundered Arctic island. Journal of Coastal Research, 21(2), 274280. West Palm Beach (Florida), ISSN 0749-0208.

\begin{abstract}
Dinkum Sands was mapped in 1949 as a small island, one link in a 95-km-long chain of barrier islands near Prudhoe Bay, Alaska. Questions about its status as an Arctic island and the submerged land ownership led to a Federal/State joint monitoring program using topographic surveys, tide gauges, and other approaches. On the basis of the results the Supreme Court concluded that Dinkum Sands is a shoal rather than an island. The shoal attracts the yearly formation of pressure ridges at least as high as $15 \mathrm{~m}$ and undergoes drastic changes in location, shape, and elevation. Pressure ridges form from 10-cm-thick new ice when shifting and compression result in crumbling and the introduction of ice slabs into the sandy gravel shoal. This leads to a seasonal increase in shoal volume and height. With summer warming and sea-ice melting, part of the ice in the crest of the shoal $(\sim 50 \%)$ melts and its height accordingly drops to below sea level. This lowering requires neither wave action nor lateral sediment transport. The original disappearance of the island in the 1950s, however, probably was not caused by diminished sediment supply from rivers or from coastal erosion, but by diminished local sediment supply through ice pile-ups or by increased erosion from wave attack. Similar changes in sediment volume as those observed in Dinkum Sands probably also occur on fully submerged shoals ranging to water depths of 20 or more meters, which are also marked by seasonal pressure ridge formation.
\end{abstract}

ADDITIONAL INDEX WORDS: Ice pile-ups, ice-regime, sediment/ice content, barrier islands, shoals, submerged lands act, land ownership, Supreme Court.

\section{INTRODUCTION}

A chain of barrier islands stretches along Alaska's Arctic coast from the Canning River in the east past Prudhoe Bay in the west, a distance of about $95 \mathrm{~km}$ (Figure 1). In 194950 the US Coast and Geodetic Survey charted the islands and the sea floor along this island chain. One apparently new island, "hundreds of yards long and hundreds of feet wide" and cresting 3-4 feet above sea level, was first observed during this survey (MANN, 1996). It was named Dinkum Sands after the survey launch Fair Dinkum, which carried a small punt Dinky Dinkum. Subsequent reports outlined in the present document, and my letter to the US Bureau of Land Management indicated that Dinkum Sands is no longer an island (MANN, 1996). With an offshore lease sale pending, the question of whether an island exists in the area became important in 1979. The Submerged Lands Act grants to Alaska that land under its tidal waters out to 3 miles from the coastline. Establishing the coastline at Dinkum Sands requires knowledge of the ground elevations in the area and of sea level. To acquire this knowledge, Alaska and the United States commissioned a joint study with a budget of over $\$ 2.5$ million. The tasks included construction and operation of three tide gauges, with one each at Dinkum Sands, Cross Island, and Narwhal Island (Figure 1). The joint project also included surveys of the geomorphic feature Dinkum Sands several

DOI: $10.2112 / 04-0167.1$ received 12 February 2004; accepted in revision 4 August 2004. times over a 4-year period. Details of this work are provided in MANN (1996).

The precise determination of a partly submerged land surface on the sloping shore face in the Arctic is problematic because of the presence of a seasonal cover of ice and snow that undergoes almost unnoticeable horizontal movement. Movement causes warping of the ice plus crumbling, breakage, and even mixing of thin ice slabs with the shallow sea bottom. In the present report, I describe (a) my own observations and a survey of the area prior to the Supreme Court hearings in 1984, (b) my observations of Dinkum Sands made during the monitoring program by the State and Federal Governments, (c) relevant information presented by witnesses, and (d) thoughts about dynamic processes on Dinkum Sands affecting the shoreline today.

Waiting for the outcome of the study and the court's decision, royalties from the lease sale accumulated in escrow and, after expenses, ultimately reached about $\$ 1.5$ billion. After the Supreme Court's decision, some of the accumulated funds were used to establish the Dinkum Sands Research Grant (for information about this Grant see http://www.sfos.uaf.edu/ npmr/dsands.html). Various Alaska marine studies are being funded from this grant each year and are administered by the North Pacific Marine Research Program.

\section{OBSERVATIONS ON DINKUM SANDS}

\section{Before Monitoring}

Early in the 20th century, LEFFINGWELL (1919) surveyed the barrier islands from the Canning River in the east west- 


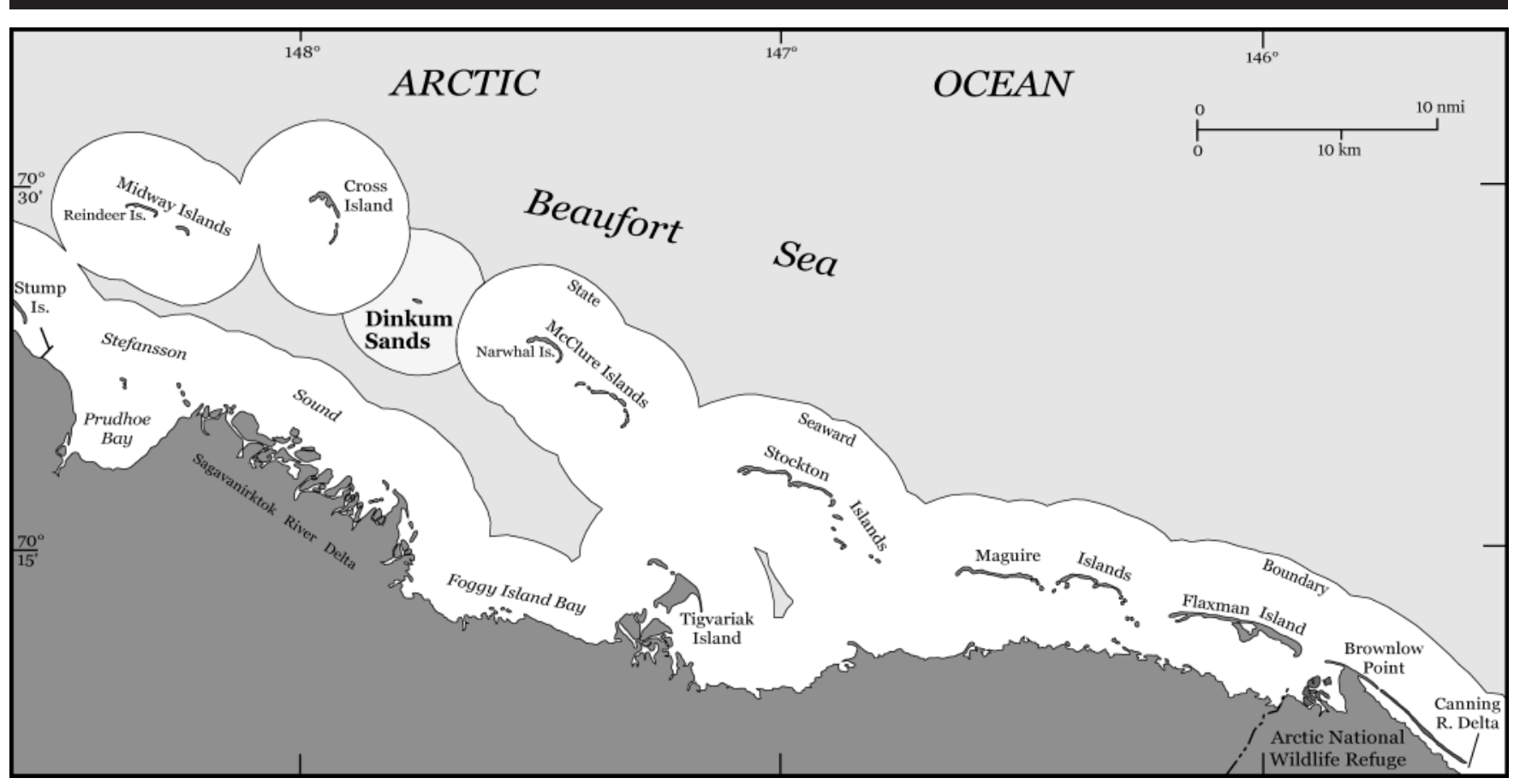

Figure 1. The chain of barrier islands, including Dinkum Sands, in 1949, also showing the state land boundary 3 mi seaward from the shoreline.

ward past Prudhoe Bay (Figure 1). His map includes spotty depth soundings and rather detailed island configurations. Completing these four surveys required setting his instruments on firm ground. He showed the shapes of neighboring Narwhal and Cross Islands (Figure 1) in detail but only water depths in the shallow regions between these islands in the vicinity of Dinkum Sands. This fact indicates that Leffingwell found no land there and had to set his instruments on the mainland to bridge the gap in the island chain. Thirty years later, from 1949-50, the US Coast and Geodetic Survey made detailed hydrographic surveys in the area. Ensign Harley Nygren (now Admiral Nygren) photographed an island described as "a new gravel bar" in late August 1949 (Figure 2). It was hundreds of meters long, $30 \mathrm{~m}$ wide, rose about $1 \mathrm{~m}$ above sea level, and was named Dinkum Sands (MANN, 1996, p. 231). During the 1979 court hearings, Nygren showed his August 1949 photograph of the island carrying a prominent navigational marker stayed to 55-gallon drums. On the basis of these surveys, the feature was mapped as an island. However, after an inspection of aids to navigation in 1955, the USS Merrick reported that the marker was no longer there (MANN, 1996, p. 232). In 1976 again the National Ocean Survey and US Coast Guard in a joint search for charted landmarks reported about Dinkum Sands: "Couldn't find island" (MANN, 1996, p. 243).

I studied the Beaufort Sea coastal zone and shelf from 1970 to 1985 , making many passes through the Dinkum Sands area with small boats in addition to low-altitude helicopter and aircraft overflights during both winter and summer. Using my observations, I reported in a letter to the US Bureau of Land Management in 1979 that the leasing map showing
Dinkum Sand as an island (Figure 1) is based on erroneous information (MANN, 1996, p. 233). To demonstrate my point, I set up transponders and ran a precisely navigated survey grid over Dinkum Sands on July 25, 1979. This survey produced echograms and high-resolution seismic records from a zig-zag pattern of lines crossing the shoal seven times and ending at the shallowest point. Wading from where my vessel ran aground, the shallowest spot was found submerged by 30-40 cm (REImnitz, Ross, and BARnes, 1980). At the time of the survey, sea level at the Prudhoe Bay tide gauge stood 10 to $20 \mathrm{~cm}$ below mean high water (MANN, 1996, p. 247). However, two weeks earlier on July 11, Alaska officials had visited the site and found gravel mounds rising about $1 \mathrm{~m}$ above sea level (MANN, 1996, p. 233).

Comparison of a contour map prepared from the 1949 survey data with that from the 1979 survey, excluding the island Dinkum Sands, shows very little change in the location and overall shape of the crest of the shoal (Figure 3). The $7-\mathrm{kHz}$ seismic profiles recorded together with depth soundings in many areas show an older, probably pre-Holocene stratum buried under the shoal by as much as 5 to $6 \mathrm{~m}$ of newer sediments. This underlying older horizon on the seismic records, however, seems to crop out under about 10 of the shallowest points of Dinkum Sands (REIMnitz, Ross, and BARNES 1980).

\section{During the Joint Monitoring Program}

\section{Tides}

Three tide gauges were installed in shacks set on floating land-fast ice landward of Cross and Narwhal Island and of 


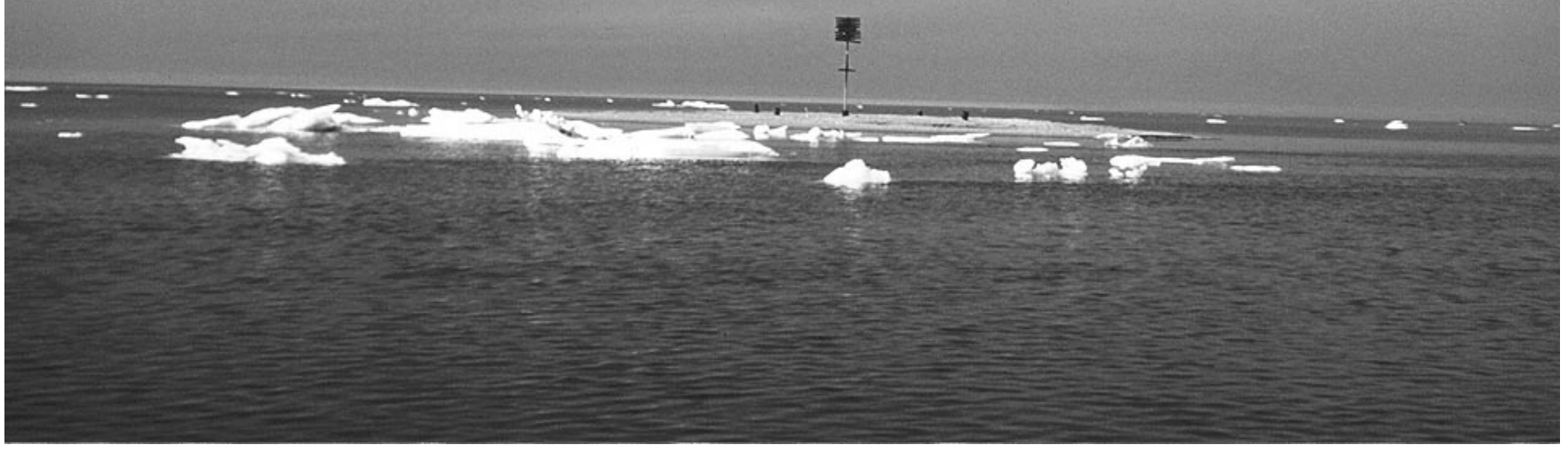

Figure 2. Dinkum Sands photographed by Nygren during the original survey in August 1949 with a marker held vertically by cables secured to buried 55 -gal drums. The sandy gravel island stood about $1 \mathrm{~m}$ above sea level.

Dinkum Sands (Figure 1). The Narwhal Island gauge recorded only 1 month of data before its destruction by sea ice in September 1980. The one at Dinkum Sands recorded for 4 months before destruction by ice, while the gauge at Cross Island survived for a full year. All gauges recorded diurnal tides of 15-cm amplitude, on which were superimposed somewhat larger wind-driven sea level fluctuations (MANN, 1996, p. 238). The largest variation in sea level is seasonal, cresting in August 30 to $45 \mathrm{~cm}$ above the lowest level of the year observed from November through December. The recorded tides served to set a reference bench mark at Dinkum Sands, against which elevations of the feature were measured. These height determinations seemed to show that the elevation of the morphological feature itself varied with time. Also, the location of the shallowest spot marked by a monument in August 1979 had shifted 350 m eastward by the spring 1980 . At that time the former high spot was submerged under more than $1 \mathrm{~m}$ of water. By May 1983, the high point had moved again, now being $30 \mathrm{~m}$ north and $150 \mathrm{~m}$ east of the original monument (MANN, 1996, p. 289).

In the present report I describe (a) my own observations and a survey of the area prior to the Supreme Court hearings in 1984, (b) my observations of Dinkum Sands made during the monitoring program by the State and Federal governments, (c) relevant information presented by witnesses, and (d) thoughts about dynamic processes on Dinkum Sands affecting the shoreline today.

Winter observations of the Dinkum Sands tide gauge shelter showed that the supporting fast ice was shifting horizontally relative to the seafloor. Similar slow movement of the fast ice destroyed all three tide gauges, each being nailed to the sea bottom by six 2-in. pipes. Slow movement of the fast ice also explains the formation of ice rubble on the crest of the shoal, discussed below.

\section{Height of the Shoal}

The topography of Dinkum Sands was measured by a contractor in March, June, and August of 1981. In an area of about $60 \times 800 \mathrm{~m}, 270$ holes were drilled through the ice in a systematic pattern and the elevations of the first show of gravel were recorded. Because of the continuing slow creep of the ice cover mentioned before and its buckling over Dinkum Sands, the top of the shoal usually is a mixture of sand and gravel with interspersed slabs of ice. This fact presents the problem of what to call the surface of the shoal. The operator of the hand-held ice drill, who has to cut hundreds of holes to record topographical profiles of Dinkum Sands, must protect the cutting edge of his tool. He therefore stops drilling at the first sign of sediment. This spot hence becomes part of the contour map of Dinkum Sands, although the drill had entered a seasonal mixture of ice and sediment.

Similar surveys were made from 1979 through 1983, and in at least four of five summers Dinkum Sands dropped to below mean high water (MANN, 1996, p. 309). On the basis of these measurements, the Special Master concluded that Dinkum Sands is not an island. During the time when melt water starts collecting in puddles on the surface (May), the crest of Dinkum Sands has irregular relief forms. Mounds of drying sandy gravel as much as $1 \mathrm{~m}$ or more above the sea surface (Figure 4) alternate with seawater-filled holes a meter or more deep. In these locations surveyors wearing hip 


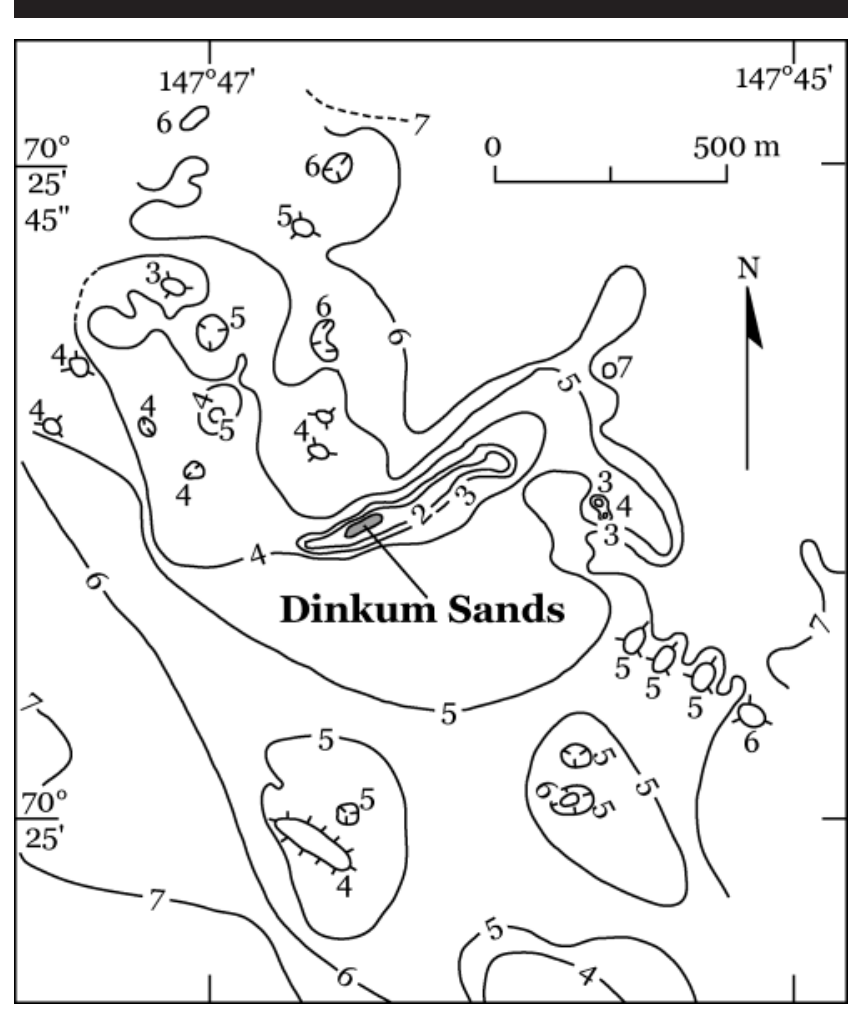

Figure 3. Water depths contoured in meters from the survey of July 25, 1979, using the sea surface at nearby Prudhoe Bay tide gauge as zero datum. Numerous semicircular closed depressions and mounds represent typical ice-wallow relief forms (REIMNITZ and KEMPEMA, 1982) caused by grounded ice.

boots sometimes had the boots filled with water. On the highest mound, the state in 1979 set a tripod flying the Alaska flag. This structure was photographed (Figure 5) from the R/V Karluk with a draft of over a meter on August 23 grounded nearby. A lack of windy days as the open-water season started in 1979 is important. The lowering and smoothing of the crest of the shoal thus was a function of melting of excess ice within the shoal, not of wave action. The sediment therefore settles largely in place, and thaw-settling of ice-rich sediment involves no lateral transport.

\section{High Ice Content in Sandy Gravel}

In May 1980 and March 1981, I joined the surveyors in their topographic surveys on Dinkum Sands. The general shape of the feature already had been defined by augering through the ice and leveling the points where the first signs of sediment were noted in the ice shavings, or where the tool entered free water. In 1981, I made four excavations through the ice by penetrating with a heavy wrecking bar $1 / 2$ to $3 / 4$ $\mathrm{m}$ into the frozen sandy gravel along a 40-m stretch of the shoal. A typical excavation exposed an irregular matrix of under 10-cm-thick, irregularly dipping ice slabs with small pockets of sandy gravel between them (Figure 6). A bulk sample representing the upper $25 \mathrm{~cm}$ of Dinkum Sands as shown in Figure 6, after melting, consisted of $50 \%$ water and $50 \%$ water-saturated sandy gravel. The gravel contained rounded clasts as much as $8 \mathrm{~cm}$ in diameter. Studies of the frozen, ice-covered crest of Dinkum Sands during the previous year had shown similar results. In both years the ice cover of Dinkum Sands consisted of hummocks with as much as $2.5 \mathrm{~m}$ relief. In 1980, the shoal was flanked by a higher pressure ridge discussed below.

The forceful introduction of ice into sediments probably is not restricted to pressure ridges at the sea surface, where it is easily observed visually. Grounded pressure ridges are prevalent in the Stamukhi Zone of the Beaufort Sea, where they are associated with shoals along the $20 \mathrm{~m}$ isobath (REIMNitz, Barnes, and Melchior, 1977). Reimnitz and KemPEMA (1984) made detailed seafloor studies, including diving traverses, in the zone of grounded pressure ridges on shoals, but they did not report any incorporated ice slabs. I suspect their occurrence, but detection during summer would require the use of very special techniques other than side scanning sonar and high-resolution seismic surveys. Comparing depth profiles of shoals from winter (April/May) and the following summer (August/September) would indicate whether ice was introduced into bottom deposits of a shoal.

\section{THE PAST AND FUTURE OF DINKUM SANDS}

With a length of over $100 \mathrm{~m}$ and height of $1 \mathrm{~m}$, large enough to erect a day beacon with stays, Dinkum Sands clearly appeared to be an island when first charted in 1949 . It seemed typical for migrating Arctic islands dominated by wave overwash (REIMNITZ, BARNES, and HARPER, 1990). The causes for the construction of the island between 1910 and 1950, and its destruction after 1950, are unknown. D.L. Inman was hired to represent the State of Alaska in the Supreme Court hearings as an expert on barrier islands. He made a case for the North Slope being a desert environment, where major sediment-supply pulses from the Brooks Range to the Canning River Fan may be followed by a quiescence of perhaps 100 years with little or no additional sediment supply. Reimnitz and Wolf (1998), however, showed that the North Slope fans and tributaries that would be feeding the island chain have been dormant throughout the Holocene epoch. We therefore need another explanation for the demise of Dinkum Sands.

Neighboring Cross and Narwhal Islands to the west and east of Dinkum Sands have broken up since first charted. Thus, LefFingwell (1919) mapped Cross Island as one arcuate body with the shape of a typical barrier island. Already in 1950, Cross Island was charted as two arcs, both migrating west southwestward. Narwhal Island was charted as one large body as late as 1950, but by 1987 the island consisted of five separate bodies (REIMNITZ, BARNES, and HARPER, 1990). Most of these small islets then developed arcuate shapes in response to dominant winds and waves from the northeast.

The disappearance of Dinkum Sands, as well as the breakup of barrier islands during the last century, are signs of sediment starvation. However, since the sediment supply from upland sources (REIMNITZ and WoLF, 1998) and from coastal erosion (Reimnitz, Graves, and Barnes 1988) was 


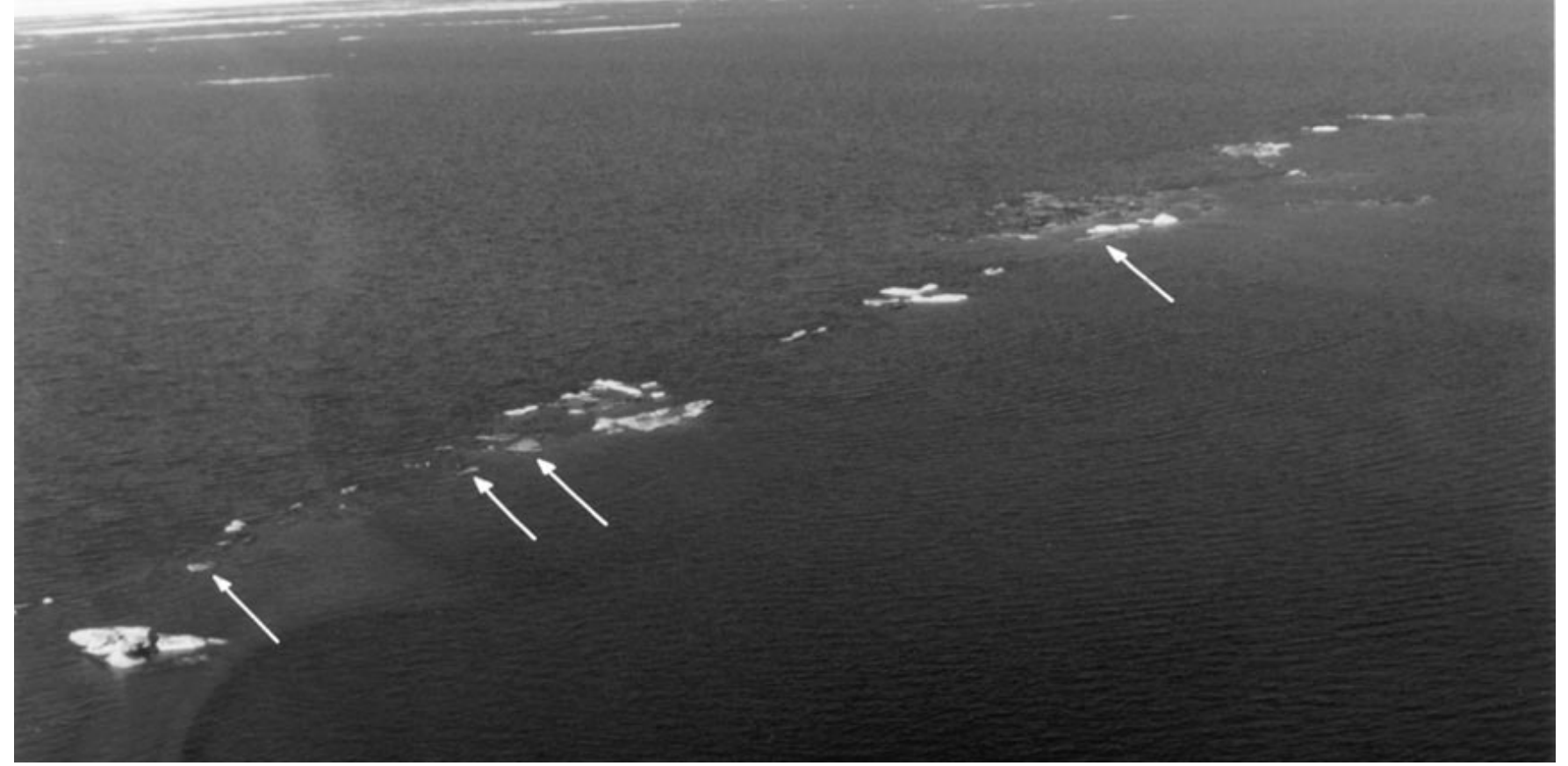

Figure 4. Aerial photograph of the shallowest segment of Dinkum Sands on July 15, 1979, viewing northwestward. Individual gravel mounds above sea level are dry, as marked by arrows. White objects represent a linear accumulation of brash ice grounded along the crest of the shoal.

not reduced significantly during that time interval, we must also evaluate changes in the third major variable, the action of sea ice.

The sediment nourishment of beaches and barrier islands by ice encroaching onto land was reviewed by REIMNITZ, BARNES, and HARPER (1990). They showed that of the two major types of encroachment, ice override and ice pile-ups, the latter brings sediment from the shore face reaching down to water depths of at least $5 \mathrm{~m}$, where the advancing ice sheet bends downward before crumbling. Pile-ups melting on beaches leave their gravelly sediment inclusions as irregular surface mounds. Beaches where pile-ups occur repeatedly before being smoothed by waves during storm surges become elevated to levels above the reach of waves. Parts of Narwhal and Cross Island are such high, "ice nourished" remnants (REIMNITZ, BARNES, and HARPER 1990), serving as witnesses for years with less wave fetch and more ice cover than today. Decreased beach nourishment by sea ice encroachment and increased wave energy in the Beaufort Sea may have brought about the demise of Dinkum Sands. Evidence for decreasing ice severity in the Beaufort Sea during summers, from logs of whaling captains reaching back to 1860, was presented by Reimnitz, BARNes, and HARPER (1990). A basin-wide decrease in ice cover generally accompanied by longer ice-melt seasons and more fetch has been documented by various authors (SERREZE et al., 1990). In view of the increasing open water observed north of Alaska during the last century, a rebuilding of Dinkum Sands as an island seems unlikely under present conditions.

\section{A YEARLY GYCLE}

With the onset of open water over the crest of the shoal there are gravel-covered remnants of ice pile-ups separated by 0.5 - to 0.8 -m-deep holes. On sunny days these exposed surface mounds of sandy gravel may dry, while the still-submerged ice continues melting, causing uneven settlement. Not only the ice, but the sandy gravel still frozen from exposure to the air during the past winter, are thawing. By late July, enough fast ice has disappeared so that even an 18-knot wind can generate waves sufficient to smooth the still rough and irregular crest of Dinkum Sands. The rapidity of smoothing was shown in depth-recorder traces of August 25 published by Reimnitz, Ross, and BARnes (1980). On these records, even ice gouge relief had already been eliminated. Cruising by the shoal in a boat in summer, its presence is revealed by peaked surface waves and also by linear accumulations of brash ice (Figure 4).

By the beginning of October, the water temperature has again approached its freezing point. A freezing storm now cools the ocean to below its freezing point, when the surface sediments still saturated with lower-salinity seawater become ice bonded, and also anchor ice starts forming on the crest of the shoal (REIMNITZ, KEMPEMA, and BARNES, 1987). By mid-October, the shoal lies under new fast ice. This ice is 


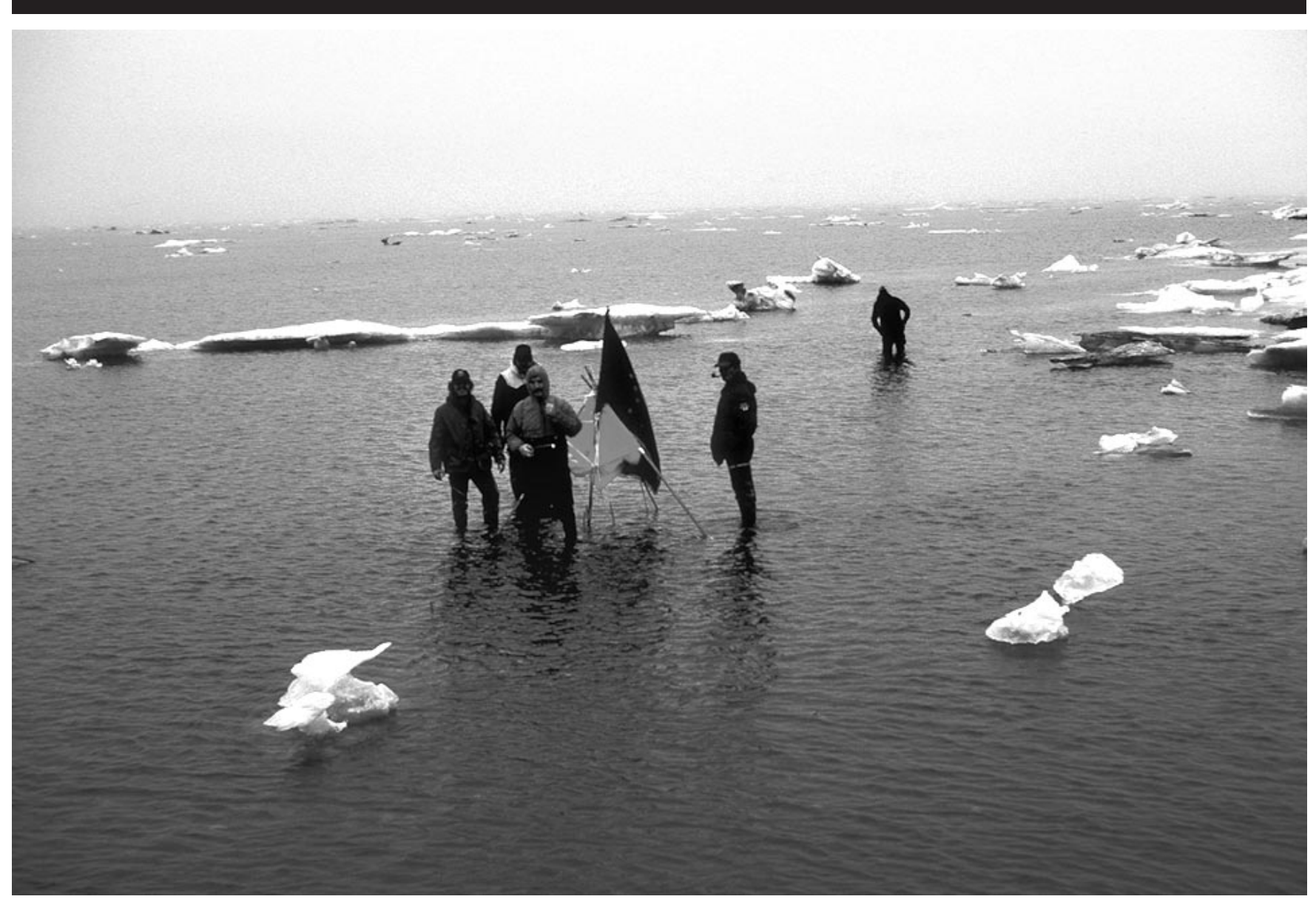

Figure 5. The highest point of Dinkum Sands surveyed during the previous winter as photographed from the grounded R/V Karluk with state and federal officials in waders on August 23, 1979. The minimum water depth at this time was about $20 \mathrm{~cm}$. The flag marks a winter pile of sand and gravel with incorporated thin slabs of ice rising about $1 \mathrm{~m}$ above sea level 2 wk earlier, showing rapid changes in early summer.

rather smooth and not deformed. It will, however, continue to creep nearly unnoticeably. On high points that reach upward into the creeping ice, breakage and crumbling occurs that can result in mixing of ice and sediment. Evidently ice bonding and anchor ice disappear shortly after formation of an ice cover, as I have not observed these features in winter SCUBA diving. The regional ice thickness continues to increase, reaching nearly $2 \mathrm{~m}$ by the end of April.

The deformation of fast ice can take a violent form. Thus, during the monitoring program, larger pile-ups occurred in two winters at Dinkum Sands, in one case reaching a height of 15 m (MANN, 1996, p. 283). Pile-ups usually are composed of ice slabs only about $10-\mathrm{cm}$ thick, indicating October/November events. The thin slabs become randomly arranged, with coarse shoreface sediment in interstices. Therefore the composition of materials penetrated in my winter excavations on the crest of the shoal most likely represented ice pile-ups formed early during the previous winter. Introduction of ice slabs into the shoal and mixing with its sediments explains the volume and height increase commonly observed in Dinkum Sands in winter (MANN, 1996).

The spring melt in the seasonal cycle usually lacks storms and therefore is uneventful compared to the other seasons. Sea level rises about $45 \mathrm{~cm}$ during summer (MANN, 1996, p. 239 ) and the rise causes ice piles and hummocks to separate and rise from the bed, releasing any attached sediment locally.

\section{CONCLUSIONS}

A submerged shoal exists now in the place where about 50 years ago a small island with $1 \mathrm{~m}$ of freeboard was reported. This island formed one link in a 95-km-long chain of Arctic barrier islands. Elsewhere around the Arctic Ocean, as for example in the Laptev Sea, islands composed of ice-rich permafrost have disappeared through processes of thaw settlement. In the case of Dinkum Sands, thaw settlement is ruled out as a cause of island disappearance. In this case a relatively warm ocean has not recently been brought in contact with frozen, ice-rich coastal plain deposits. Neighboring islands in the chain, like Narwhal and Cross Island, carry signs of sediment starvation. But a decreasing sediment supply, either from upland sources via rivers or from coastal erosion, is ruled out as a cause of sediment starvation in the barrier island chain. 


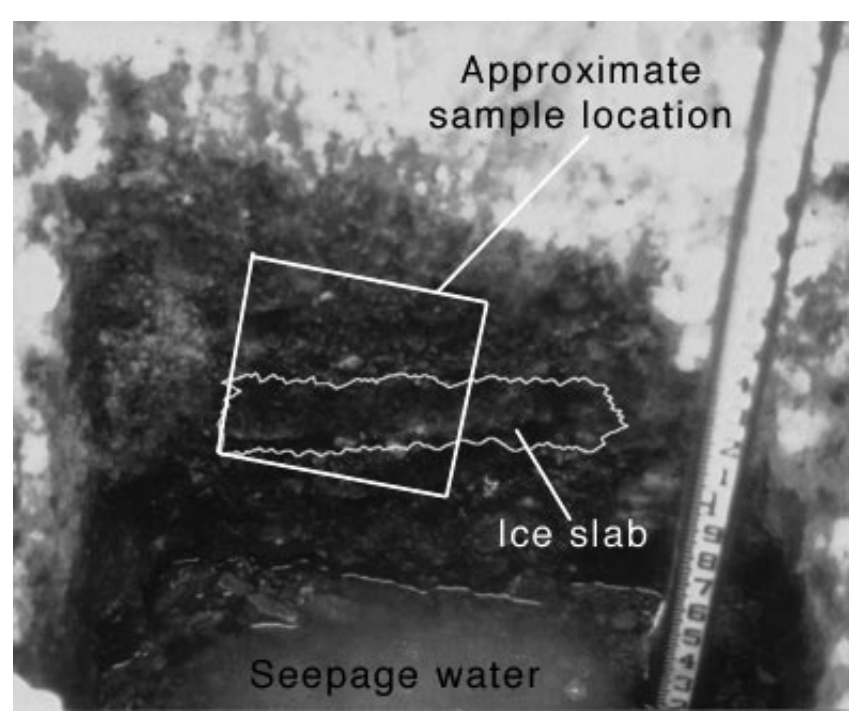

Figure 6. An approximately 50-cm-deep, vertical exposure of ice-rich sandy gravel excavated in the crest of Dinkum Sands, with water accumulating in the bottom. Irregular white outline defines a slab of ice. Scrapings from a $25-\mathrm{cm}$ square in middle of gravel exposure melted in a container showed the sample to consist of $50 \%$ water over saturated sandy gravel.

A significant sediment supply mechanism for Arctic beaches is encroachment of fast ice onto land transporting shoreface material up-slope. The most important feeding mechanism by the various types of ice encroachment is through ice pile-ups, which usually end within $20 \mathrm{~m}$ of the shoreline. Here crumbled ice mixed with coarse shoreface deposits melts the next summer. Melting leaves the sediment in form of mounds on beaches or islands. Winter excavations at the highest points above sea level in Dinkum Sands showed that they were caused by pile-ups that are eliminated by summer melting and wave action. Evidence suggests that submergence of the original island was caused by a change in the environment from ice stressed to wave dominated.

Today the volume of Dinkum Sands is seasonally inflated through the introduction of ice slabs from pile-ups. Similar processes on permanently submerged shoals, usually marked by winter pressure ridges, occur to at least $20 \mathrm{~m}$ of water depth. Here seasonal volume and depth changes probably also occur through introduction of ice into these shoals. Demonstrating their icy composition, however, will be much more difficult than in the case of Dinkum Sands being at the sea surface.

\section{ACKNOWLEDGMENTS}

Critical reading of this paper by Bruce Rogers and Jerry Brown resulted in significant improvements. Hajo Eicken directed me to the latest literature on the extent of Arctic sea ice. I thank them for their time and efforts!

\section{LITERATURE CITED}

BARnes, P.W. and Reimnitz, E., 1988. Construction of an arctic barrier island by alternating sea-ice pile-up and overwash. In: GALLOWAY, J.P., and Hamilton, T.D. (eds.), US Geological Survey studies during 1987. US Geological Survey Circular 1016, pp. 180182.

Leffingwell, E. DE K., 1919. The Canning River region, northern Alaska. US Geological Survey Professional Paper 109, 251p.

Mann, J.K., Special Master, 1996. The Supreme Court of the United States, No. 84, Original: USA, Plaintiff, versus State of Alaska. $565 \mathrm{p}$.

Reimnitz, E.; BARnes, P.W., and Melchior, J., 1977. Changes in barrier island morphology-1949-1975, Cross Island, Beaufort Sea, Alaska: US Geological Survey Open File Report 77-477, 14p.

Reimnitz, E.; Ross, R., and Barnes, P.W., 1980. Dinkum Sands. US Geological Survey Open File Report 80-360, 11p.

Reimnitz, E. and Kempema, E.W., 1984. Pack ice interaction with Stamukhi Shoal, Beaufort Sea, Alaska. In: BARNES, P.W., Schell, M.S., and Reimnitz, E. (eds.), The Alaskan Beaufort Sea. Orlando, FL: Academic Press, Inc., pp. 159-181.

Reimnitz, E.; Kempema, E.W., and BARnes, P.W., 1987. Anchor ice, seabed freezing, and sediment dynamics in shallow arctic seas. Journal of Geophysical Research, 92(14), 671-678.

Reimnitz, E.; Graves, S.M., and Barnes, P.W., 1988. Map showing Beaufort Sea coastal erosion, sediment flux, shoreline evolution, and the erosional shelf profile. US Geological Survey, Map I-1182G. $22 \mathrm{p}$.

ReImnitz, E.; BARNES, P.W., and HARPER, J.R., 1990. A review of beach nourishment from ice transport of shoreface materials, Beaufort Sea, Alaska. Journal of Coastal Research, 6(2), 439-470.

Reimnitz, E. and Wolf, S.C., 1998. Are North Slope surface alluvial fans pre-Holocene relicts? U.S. Geological Survey Professional Paper $1605,9 p$.

Serreze, M.C.; Walsh, J.E.; Chapin, F.S., III; OsterkamP, T.; Dyurgerov, M.; Romanovsky, V.; OChel, W.C.; Morison, I.; ZHANG, T., and BARRY, R.G., 2000. Observational evidence of recent change in the Northern high-latitude environment. Climatic Change, 46, 159-207. 